University of Nebraska - Lincoln

DigitalCommons@University of Nebraska - Lincoln

Diets of Kauai's invasive rose-ringed parakeet (Psittacula krameri): evidence of seed predation and dispersal in a humanaltered landscape

\author{
Aaron B. Shiels \\ USDA, APHIS, Wildlife Services, aaron.b.shiels@aphis.usda.gov \\ William P. Bukoski \\ USDA/APHIS/WS
}

Shane R. Siers

USDA, APHIS, Wildlife Services

Follow this and additional works at: https://digitalcommons.unl.edu/icwdm_usdanwrc

Part of the Life Sciences Commons

Shiels, Aaron B.; Bukoski, William P.; and Siers, Shane R., "Diets of Kauai's invasive rose-ringed parakeet (Psittacula krameri): evidence of seed predation and dispersal in a human-altered landscape" (2018). USDA Wildlife Services - Staff Publications. 2124.

https://digitalcommons.unl.edu/icwdm_usdanwrc/2124

This Article is brought to you for free and open access by the U.S. Department of Agriculture: Animal and Plant Health Inspection Service at DigitalCommons@University of Nebraska - Lincoln. It has been accepted for inclusion in USDA Wildlife Services - Staff Publications by an authorized administrator of DigitalCommons@University of Nebraska - Lincoln. 


\title{
Diets of Kauai's invasive rose-ringed parakeet (Psittacula krameri): evidence of seed predation and dispersal in a human-altered landscape
}

\author{
Aaron B. Shiels • William P. Bukoski $\cdot$ Shane R. Siers
}

Received: 7 July 2017/ Accepted: 18 November 2017 / Published online: 30 November 2017

(C) Springer International Publishing AG, part of Springer Nature (outside the USA) 2017

\begin{abstract}
Rose-ringed parakeets (Psittacula krameri) are the world's most successful introduced parrots, and $>2000$ individuals reside on Kauai, Hawaii. These birds destroy crops, but impacts to other native and non-native species are largely unknown. Our study objectives on Kauai were to determine: (1) diets of rose-ringed parakeets at five sites $(n=9-25$ per site), by sex, through crop and gizzard analysis and carbon and nitrogen stable isotope analysis, and (2) whether birds are dispersing or depredating seeds. We found $100 \%$ of birds $(n=64)$ were eating plant material and $80 \%$ of their diet was seed; males had more food in their crops and gizzards than did females. Corn (Zea mays) was eaten by $67 \%$ of birds and averaged $31 \%$ of mass in crops and gizzards. Invasive yellow guava (Psidium guajava) was eaten by $97 \%$ of birds and averaged $30 \%$ of their diet. Parakeets are potentially dispersing yellow guava seeds, as $66 \%$ of birds had intact guava seeds, and each
\end{abstract}

A. B. Shiels $(\bowtie)$

USDA, APHIS, WS, National Wildlife Research Center, 4101 LaPorte Avenue, Fort Collins, CO 80521, USA e-mail: Aaron.B.Shiels@aphis.usda.gov

W. P. Bukoski

USDA, APHIS, WS, 3901 Mokulele Loop Unit 20, Lihue, Kauai, HI 96766, USA

S. R. Siers

USDA, APHIS, WS, National Wildlife Research Center, Hawaii Field Station, P.O. Box 10880, Hilo, HI 96721, USA bird had an average of three intact seeds. Diets differed statistically among sites. Parakeets from Lihue Airport did not have any corn, and isotopic carbon values also supported low feeding on corn by birds at Lihue Airport. No seeds of native plants were identified in rose-ringed parakeet diets. Our findings of a diverse plant diet, frequent seed predation, and potential to disperse invasive species' seeds implies that land managers in agricultural, urban, and natural areas should be concerned with the current expansion of these invasive birds on Kauai and elsewhere.

Keywords Fruit and seed diet · Hawaiian Islands . Parrot feeding $\cdot$ Stable isotope $\cdot \delta^{15} \mathrm{~N} \cdot \delta^{13} \mathrm{C}$

\section{Introduction}

Parrots are often highly destructive birds, and are well known to damage crops, private property, and natural resources. The rose-ringed parakeet (Psittacula krameri) is the world's most successful introduced parrot species, having established in at least 35 countries. Because of their cavity-nesting behavior and overlap in diet with some native birds, rose-ringed parakeets may threaten or otherwise outcompete some native birds and bats (Butler 2003; Fletcher and Askew 2007; Strubbe and Matthysen 2007). However, agricultural damage by rose-ringed parakeets, leading to 
significant economic losses, is typically the most prominent concern with these birds.

Rose-ringed parakeets are opportunistic granivores and frugivores; they primarily consume dry and fleshy fruits and seeds (Ali and Ripley 1969; Clergeau and Vergnes 2011). In their native range, many farmers consider the rose-ringed parakeet to be the most serious avian pest because of the heavy damage that they cause to agricultural crops (e.g., corn (Zea mays), sorghum (Sorghum spp.), rice (Oryza spp.), safflower (Carthamus tinctorius), sunflower (Helianthus spp.)), fleshy fruits, and stored grains (Shivanarayan et al. 1981; Dhindsa and Saina 1994; Mukherjee et al. 2000). For example, rose-ringed parakeets reduced yields of corn and sorghum in India by $74-81 \%$ (Reddy 1998, 1999). Through crop and gizzard analysis of rose-ringed parakeets in India, adults and nestlings were shown to have fed primarily on sorghum, corn, and sunflower (Shivanarayan et al. 1981; Sani et al. 1994). In Pakistan, rose-ringed parakeets are a serious pest of corn, rapeseed (Brassica napus), and fruit crops, particularly mangos (Mangifera spp.), citrus, and guava (Psidium spp.) (Bashir 1979). Such seed and fruit consumption translates into large economic loses, and Bashir (1979) reported that the annual loss of 97,000 tons of corn seed caused by rose-ringed parakeets in Pakistan was equivalent at the time to U.S. \$15 million.

Diet assessments of birds helps reveal their feeding habits, and thus their potential to impact the environment. Crop and gizzard content analysis can be a direct assessment of immediate and short-term diet (e.g., minutes to hours after feeding), whereas stable isotope analysis $\left(\delta^{15} \mathrm{~N}\right.$ and $\left.\delta^{13} \mathrm{C}\right)$ of an individual's tissues can be an indicator of longer-term (e.g., weeks to years) average diet (e.g., Shiels et al. 2013). The growing numbers of introduced rose-ringed parakeet populations worldwide have raised concern for their potential involvement in native biodiversity loss, particularly on remote islands that lacked native parrots, such as in Hawaii. In their introduced range, rose-ringed parakeets may feed on both native and non-native plants (Cramp 1985; Strubbe and Matthysen 2007; Clergeau and Vergnes 2011), and by doing so they probably destroy the majority of the seeds that they consume. In the U.K., they are known to feed on berries of native holly (Ilex spp.) and elder (Sambucus spp.), and seeds of native hornbeam (Carpinus betulus) and ash (Fraxinus excelsior) (Cramp 1985). Additional native trees, such as ash, hornbeam, maple (Acer campestre), yew (Taxus baccata), birch (Betula pubescens), alder (Alnus glutinosa), and willow (Salix alba), were consumed by rose-ringed parakeets that had colonized Paris, France (Clergeau and Vergnes 2011). Despite their documented consumption of some native plants in Europe, no reports yet exist indicating that roseringed parakeets are altering the natural or seminatural environment through their feeding ecology (Tayleur 2010). In Australia, however, rose-ringed parakeets are known to strip bark, killing some trees and possibly shifting the local tree community composition and structure (Fletcher and Askew 2007). Reports of damage to native species in the U.S. are lacking, though they have been observed feeding on some native plants in Hawaii, including Acacia koa and endemic palms (Pritchardia spp.) (W. Bukoski, pers. obs.). Additionally, there is potential for roseringed parakeets to spread non-native or invasive plants if consumed seeds are regurgitated or if seeds are small enough to pass intact through the bird's digestive tract. Therefore, as these parakeets expand in numbers, they have the potential to alter natural areas through their feeding behavior.

We evaluated the diets of rose-ringed parakeets that were captured on the southern part of Kauai Island, Hawaii, where their activity and roosting densities appear the highest across the Hawaiian Islands. Our objectives were to determine: (1) diets of rose-ringed parakeets through digestive tract (crop and gizzard) analysis and carbon and nitrogen stable isotope analysis, (2) the relative abundances of crop and non-crop plants consumed at five locations on Kauai by both sexes, and (3) whether it is likely that these birds are dispersing either native or non-native seeds or if they are solely acting as seed predators. From earlier investigations of rose-ringed parakeets in southern Kauai, we were expecting that the majority of the diet of these birds would be corn, as radio-tracked birds would feed in cornfields each day near their roost (Gaudioso et al. 2012).

\section{Methods}

Study site

Five locations, all within a rural-suburban landscape, were selected for rose-ringed parakeet harvest on the 
southern portion of Kauai (from Kekaha in the east to Lihue in the west). Elevation was approximately 3-50 $\mathrm{m}$ a.s.1., mean annual temperature averaged $24{ }^{\circ} \mathrm{C}$, and mean annual rainfall averaged 480-1107 mm (Giambelluca et al. 2013). The study sites were chosen based on active control of roseringed parakeets in these locations for both crop protection (four sites) and airstrike hazard (Lihue). Capturing rose-ringed parakeets in additional areas, including fruit orchards and natural areas, was attempted, but none of these attempts proved successful. At least two roosts of approximately 1000 birds each were present within the study area at the time of harvest, and the specific locations of the roosts were in the towns of Poipu and Lihue.

\section{Study species}

Rose-ringed parakeets are relatively large parakeets (40 + cm body length, 110-182 g; Butler 2003) that are native to Asia and Africa. These birds have tails approximately equal in length to their bodies, and are of bright green plumage with red bills. Adult males have a dark ring (sometime reddish) around the neck, hence the naming of this species as the rose-ringed, or ring-necked, parakeet. Aside from anatomical features, juvenile males cannot be readily distinguished from adult or juvenile females. These cavity-nesting birds are highly social, foraging, roosting, and loosely nesting in the same areas (Butler 2003; Avery and Shiels 2017).

Large diameter $(>40 \mathrm{~cm})$ trees appear to be the preferred nesting resources in both the U.K. (Butler 2003) and in Hawaii (Gaudioso et al. 2012). The median clutch size is four eggs, yet two fledglings per nest is common (Butler 2003; Lambert et al. 2009). In the Hawaiian Islands, rose-ringed parakeets have established populations on at least the islands of Kauai and Oahu (Avery and Shiels 2017). In their introduced range, they generally establish night roosts on tree branches or on palm fronds (Sheehey and Mansfield 2015); royal palms (Roystonea spp.) are the only known night roost for these birds on Kauai (Gaudioso et al. 2012). The rose-ringed parakeet population on Kauai has risen to over 2000 individuals in the last 40 years (Gaudioso et al. 2012), and there is recent concern by farmers and residents on Kauai of the growing rose-ringed parakeet population and the formidable damage that they are causing.
Additionally, residents have voiced concerns about the large abundances of feces below roosts and noise from the parakeet calls and shrills (Avery and Shiels 2017).

Diet assessment and analysis

In April 2015, and from January to May 2016, roseringed parakeets were harvested by shotgun from each of the five sites: Kekaha $(n=9)$, Kekaha/Syngenta $(n=25)$, Waimea $(n=9)$, Field $102(n=10)$, and Lihue $(n=11)$. The dominant vegetation where parakeets were collected was corn (i.e., corn fields) for all sites except Lihue (adjacent to Lihue Airport), which had a mixture of primarily grass, shrubs, and some trees. Individuals were placed in labeled plastic bags and stored in a freezer for several months until the digestive tract (crop and gizzard) and feathers could be extracted from the carcasses and shipped (frozen) to USDA, NWRC (Hilo and Fort Collins). Contents of the crops were not differentiated from those of the gizzards. The combined crop and gizzard contents were swirled for $5 \mathrm{~min}$ in water with a few drops of liquid dishwashing soap to separate gastric juices, sieved through a $0.4 \mathrm{~mm}$ sieve, then placed in an oven for $72 \mathrm{~h}$ at $60{ }^{\circ} \mathrm{C}$. Once removed from the oven, each sample was sorted to the lowest taxonomic unit possible; samples were generally sorted without a microscope. There were two types of unidentifiable seeds that were relatively common based on mass; to identify these two seed types, a portion of the chloroplast trnL intron was PCR amplified from genomic DNA extracted from the seeds using the $\mathrm{c}$ and h trnL primers (Taberlet et al. 2007). The most abundant sequences for each sample were then compared to sequences stored in National Center for Biotechnology Inventory nt nucleotide and taxonomy database (see Craine et al. 2016 for details on procedures). Relative abundance (percent) of each food item by mass was determined for each sample by weighing the food item and the total sample. The frequency of occurrence (percent) for each food type was calculated by the presence of each of the food types in a sample (individual) divided by the total number of samples. Plant food types were also categorized as fruit, seed, bark, wood, and miscellaneous.

To augment the short-term diet of crop and gizzard analysis, the trophic positions of these rose-ringed 
parakeets were assessed using stable isotope analysis. For three of the five sites (Kekaha, $n=9$, Field 102, $n=10$, and Lihue, $n=11$ ), a primary wing feather from each individual was analyzed for isotopic carbon $\left(\delta^{13} \mathrm{C}\right)$ and nitrogen $\left(\delta^{15} \mathrm{~N}\right)$. Previous studies using feathers in stable isotope analyses have shown that 10 individuals is a reasonable number to obtain good isotope estimates (Jackson et al. 2011). Prior to analysis, each entire feather, including calamus, was cut into fine ( $2 \mathrm{~mm}$ length) fragments and dried at $60{ }^{\circ} \mathrm{C} ; \quad \delta^{13} \mathrm{C}$ and $\delta^{15} \mathrm{~N}$ were then determined at University of Hawaii at Hilo (UH) Analytical Lab (Hilo, Hawaii). As potential diet items of rose-ringed parakeets, seeds and fruit from three species were also collected and analyzed isotopically. Fruit and seed of the non-native Chinese fan palm (Livistona chinensis) were collected fresh near the Lihue site. Due to limited access and/or non-permissible seed harvest at the four remaining sites where birds were harvested, we were not able to obtain fresh seed of corn, and yellow guava (Psidium guajava) was not in fruit during our collection period; thus, seeds of these species were extracted from crops and gizzards of randomly chosen parakeets within our sample that contained these seeds. All seeds and fruits $\left(n=3\right.$ each) were heated at $60{ }^{\circ} \mathrm{C}$ for $72 \mathrm{~h}$, and ground to a fine dust before being sent for $\delta^{13} \mathrm{C}$ and $\delta^{15} \mathrm{~N}$ analysis at UH Analytical Lab.

\section{Statistical analysis}

The percent relative abundances of food types were compared among the five sites by parametric and nonparametric ANOVAs. Corn, yellow guava, and 'other' (i.e., everything that was not corn or guava) were the three categories with sufficient representation for statistical comparisons among the five sites. Yellow guava and 'other' categories met parametric assumptions of ANOVA after arcsine square-root transformations (yellow guava needed additional logtransformation); the remaining comparisons involving corn did not meet parametric assumptions, so the nonparametric Kruskal-Wallis test was used to assess significant differences among parakeet food types from the five sites. We also used ANOVA to test whether amounts of total crop-gizzard content, percent total seed, corn, or guava differed by parakeet sex or juvenile status. Post-hoc Tukey's tests or package "pgirmes" (for corn) was used to assess significance between sites, and sexes or juvenile status; significance was based on $P<0.05$. All statistical analyses were completed in $\mathrm{R}$ version 3.2.3.

\section{Results}

Of the 64 rose-ringed parakeets harvested in 2015-2016 in southern Kauai, there were 34 adult males, 16 adult females, and 14 juveniles for which sex could not be determined. Corn was in fruit/seed when parakeets were harvested from three of the four sites with corn as the dominant vegetation; Kekaha (sampled in 2015) did not have corn in seed in the field when birds were harvested.

All parakeets harvested had vegetation in their crops and gizzards, and $80 \%$ of the contents (by mass) was seed. Many of the food items were unidentifiable to genus or species, and there were items present (generally in very low abundance) that included charcoal, wood, grass (Poaceae) seeds, sunflower (Helianthus sp.) seeds, feathers (most likely from preening), and an additional 33 unknown food items of plant material, some of which were described as fleshy fruit, seed coats, fibrous material, shiny material, coffee-like (Coffea sp.) seeds, endosperm, woody material, and cork (bark). Two types of seeds that were commonly found in crop and gizzard contents but were unidentifiable based on morphological features were genetically identified as leucaena (Leucaena leucocephala) and acacia (Acacia sp.). No insect or other animal matter was found in rose-ringed parakeet crops and gizzards.

Despite the diversity of food items that were mostly unidentifiable to genus or species, there were six distinguishable categories of plant material that, by mass (g), made up most of the rose-ringed parakeet diet: corn, yellow guava, leucaena seeds, sunflower seeds, acacia seeds, and other (Fig. 1). The top three main food categories were approximately evenly represented (31\% corn, 30\% yellow guava, 28\% other; Fig. 1). The most frequently occurring food items were corn, which occurred in $67 \%$ of all birds, and yellow guava, which occurred in $97 \%$ of all birds. Most of the corn material in the crop and gizzard was the kernel/seed, but about $20 \%$ by mass was the corn cob. Despite the birds undoubtedly consuming some of the fruit tissue when consuming yellow guava, all of the identifiable material of yellow guava was seed. 


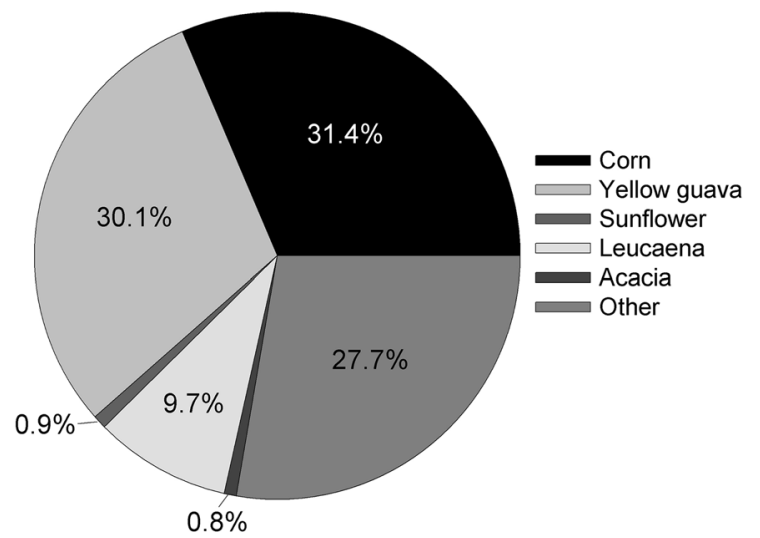

Fig. 1 Mean relative abundances of identifiable dietary items in crop-gizzards of rose-ringed parakeets $(n=64)$ from Kauai, Hawaii

When the relative abundance of corn, yellow guava, and 'other' (which included sunflower, leucaena, and acacia) were compared among the five sites, there were significant differences present (Fig. 2). The significant differences among sites for corn $\left(P<0.0001 ; \quad \chi^{2}=42.3, \quad d f=4\right)$ were primarily attributable to the relatively high corn contents in birds from Kekaha compared to all other sites ( $P<0.05$ for each comparison), as well as greater corn contents in birds from Kekaha/Syngenta relative to Lihue and Field $102(P<0.05$ for each comparison). Parakeets from the Lihue site $(n=11)$ did not have any corn in their crop and gizzards (Fig. 2). There were significant differences among the five sites

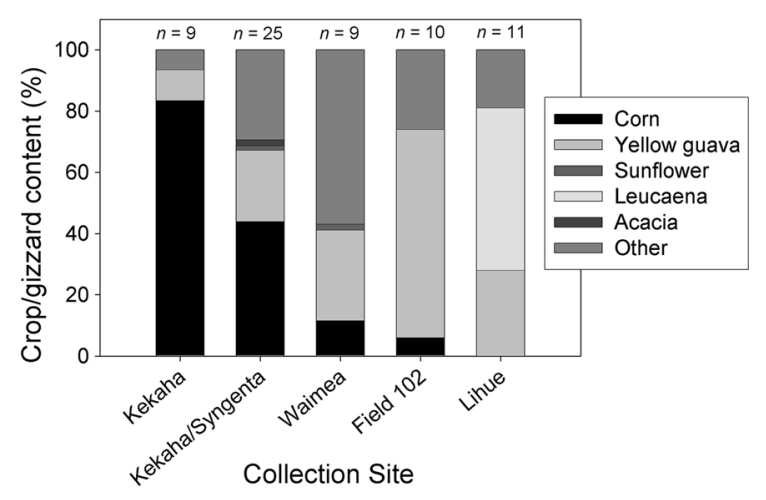

Fig. 2 Mean relative abundances (percent of total mass) of identifiable dietary items in crop-gizzards of rose-ringed parakeets harvested from five sites in southern Kauai, Hawaii. Leucaena (Leucaena leucocephala), sunflower (Helianthus sp.), acacia (Acacia sp.), and all other items aside from corn and yellow guava were grouped in 'other' category for statistical analysis for yellow guava content in parakeets $(P<0.0001$; $F_{4,59}=8.0$ ), and post hoc Tukey's test revealed that birds from Field 102 had more yellow guava in crop and gizzards than did birds from each of the other sites (i.e., Waimea: $P=0.0047$; Kekaha: $P<0.0001$; Kekaha/Syngenta: $P<0.0001$; Lihue: $P=0.0102$; Fig. 2). Interestingly, Field 102 parakeets also had significantly less total contents in their crop and gizzards (average $\pm \mathrm{SE}: 0.5 \pm 0.1 \mathrm{~g} ; \quad P<0.0001$; $F_{4,59}=15.3$ ) than all other sites (i.e., Waimea: $1.7 \pm 0.5 \mathrm{~g}, \quad P=0.0116 ; \quad$ Kekaha: $4.6 \pm 0.7 \mathrm{~g}$, $P<0.0001 ; \quad$ Kekaha/Syngenta: $2.9 \pm 0.3 \mathrm{~g}$, $P<0.0001 ; \quad$ Lihue: $1.8 \pm 0.3 \mathrm{~g}, \quad P=0.0011)$; Kekaha parakeets had significantly greater total contents than did Lihue $(P=0.0256)$ and Waimea $(P=0.0084)$ parakeets. Additionally, the percentage of total seed in parakeet crop and gizzards was significantly different among sites $(P=0.0002$; $F_{4,59}=6.7$ ), and birds harvested in Waimea had a lower proportion of seed $(45.7 \pm 10.4 \%)$ than those harvested from Lihue $(87.9 \pm 6.7 \% ; P=0.0012)$ and Kekaha $(94.0 \pm 5.4 \% ; \quad P=0.0002)$; Kekaha/Syngenta parakeets also had lower proportions of seed $(72.1 \pm 4.4 \%)$ than did Kekaha parakeets $(P=0.0319)$.

For 'other' category, which included sunflower, leucaena, acacia, and all other items aside from corn and yellow guava, there was a significant difference among the five sites $\left(P<0.0001 ; F_{4,59}=13.9\right)$; birds from Lihue had significantly more 'other' material in their crops and gizzards than did those from Field 102 $(P=0.0004)$, Kekaha $(P=0.0001)$, and Kekaha/ Syngenta $(P=0.0007)$. Approximately $10 \%$ of the 'other' category was leucaena seeds (Fig. 1), and these seeds were found only in birds from Lihue (Fig. 2). Additionally, birds from Waimea had significantly more 'other' material than did those harvested at Field $102(P=0.0169)$, and Kekaha $(P<0.0001)$, whereas Kekaha had significantly less 'other' material than Kekaha/Syngenta ( $P=0.0039)$ (Fig. 2).

Sex or juvenile status did not reveal significant differences in total seed $\left(P=0.600 ; F_{2,61}=0.5\right)$, corn $\left(P=0.418 ; F_{2,61}=0.885\right)$, or yellow guava $\left(P=0.301 ; \quad F_{2,61}=1.2\right)$ in crops and gizzards. However, the total content $(\mathrm{g})$ of material in the crop and gizzard was significantly different among sexes and juvenile status $\left(P=0.0391 ; F_{2,61}=3.42\right)$, and this difference was attributable to the greater content in male parakeets $(2.7 \pm 0.3 \mathrm{~g})$ than female parakeets 
$(1.7 \pm 0.5 \mathrm{~g} ; \quad P=0.0323)$. The juvenile birds $(n=14)$, of which sexes could not be determined, did not differ from either sex of adult birds, and their average crop-gizzard contents were $2.3 \pm 0.5 \mathrm{~g}$.

Intact seeds in the crop and gizzard present the possibility of seed dispersal by rose-ringed parakeets. Through our crop and gizzard content analysis and presence of seed material, there was, on average, a minimum of 2.4 plant species' seeds present in each rose-ringed parakeet. Whole, or intact, seeds are most likely candidates for seed survival and potential dispersal by birds. Sixty-six percent of parakeets had intact yellow guava seeds, and there was an average of $3.0 \pm 0.6$ (min: 0 , max: 26) intact yellow guava seeds in each parakeet's crop or gizzard. The average number of intact seeds of unknown species in each bird was $8.5 \pm 3.3$ (min: 0, max: 150 ), and the total number of intact seeds identified per individual averaged $11.6 \pm 3.3$ (min: 0, $\max : 150$ ). Only three individual parakeets had intact corn seeds in their crops or gizzards, and two of the three birds had just one intact seed and the third bird had three intact corn seeds. The majority of seed mass (all taxa combined) was represented by destroyed seeds.

Stable isotope analysis of feather tissue revealed that parakeets from different sites occupy, or feed at, an equivalent trophic level (i.e., $\delta^{15} \mathrm{~N}$; Fig. 3). However, the gradient of $\delta^{13} \mathrm{C}$ across sites may represent variation in proportional corn consumed; corn is a $\mathrm{C}_{4}$ plant, thus less negative in $\delta^{13} \mathrm{C}$ than the two $\mathrm{C}_{3}$ plants (Fig. 3). Parakeets at Lihue airport had the most

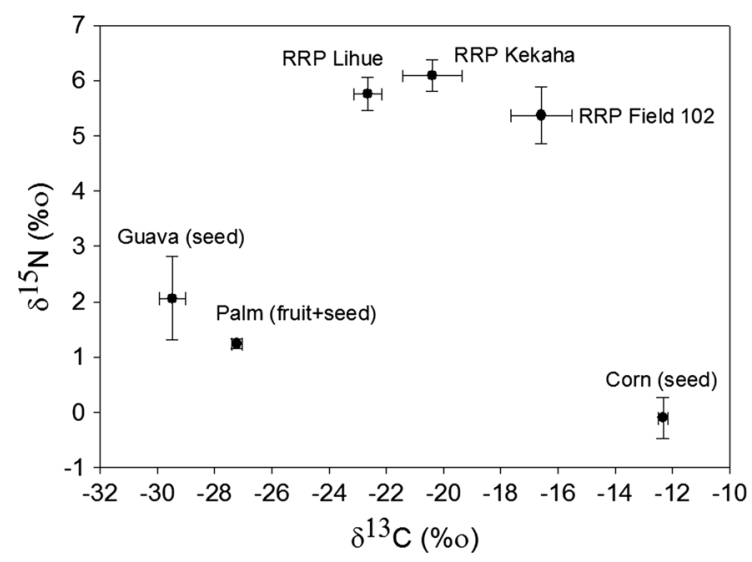

Fig. 3 Mean \pm SE $\delta^{15} \mathrm{~N}$ and $\delta^{13} \mathrm{C}$ of rose-ringed parakeet (RRP) from three locations (Lihue airport, Kekaha, and Field 102) in southern Kauai Island, Hawaii, and some of their potential food items (yellow guava, fan palm, and corn) negative $\delta^{13} \mathrm{C}$ whereas those in Field 102 (a corn field) tended to have less negative $\delta^{13} \mathrm{C}$.

\section{Discussion}

Our dietary assessment of the spreading population of rose-ringed parakeets on Kauai revealed that these birds appear to be strict herbivores, where seeds of both crop plants (primarily corn) and non-crop plants (yellow guava) are the dominant foods, at least during January-May, and the majority of the seeds appear to be destroyed by these birds following consumption. While we expected corn to be the dominant food item, birds from one site (Lihue) did not have any corn in their crop-gizzard, and stable isotope analysis revealed that the longer-term diet of the Lihue birds had less corn in their diets than did birds from other sites in southern Kauai. Although corn and guava have been previously documented as being consumed by roseringed parakeets in Pakistan (Bashir 1979), we did not expect yellow guava to comprise such a large part of the parakeet diet on Kauai. Furthermore, the abundance of intact seeds of yellow guava in crops and gizzards (average of three seeds per individual) raises the possibility that these parakeets could be dispersing seeds of this invasive plant species. Opportunistic foragers, like many parrot species including the roseringed parakeets, typically have an unspecialized herbivorous diet. Renton (2001) observed that the lilac-crowned parrots (Amazona finschi) exhibited a highly flexible diet, and diet switching was observed during low resource availability and resulted in a narrow dietary breadth such that few plant species comprised the majority of their diet. Taken together, the 64 rose-ringed parakeets that we analyzed had consumed about 40 distinct food items. In this regard, their diet appears flexible. However, about $60 \%$ of their overall diet by mass is accounted for by just two plant species-corn and yellow guava. Therefore, although these parakeets appear to have flexible and opportunistic foraging, their targeting of a few available species has translated into a semi-specialized diet, resulting in potentially high levels of damage for these two plant species on Kauai, and particularly so for corn. Seed corn, which is an important economic resource in southern Kauai, is well known to be heavily damaged by rose-ringed parakeets via their daily feeding behavior (Gaudioso et al. 2012). In fact, 
management techniques such as harassment and lethal control in corn fields in Hawaii has been estimated to cost hundreds of thousands of dollars each year (Koopman and Pitt 2007), and currently large nets are placed over whole fields in Kauai to help reduce corn damage by rose-ringed parakeets. Additional agricultural products such as sunflower and possibly coffee were also noted in the crops and gizzards of the studied parakeets. As future agriculture and land use may change on Kauai, and assuming that the parakeet population will persist and likely expand, growers may benefit from knowing the vulnerabilities to rose-ringed parakeets of the types of crop species that they are considering growing.

We are unable to determine whether the intact seeds found in rose-ringed parakeet crops and gizzards in this study would have survived the grinding action of the gizzard. Thabethe et al. (2015) assessed the effects of rose-ringed parakeet gut passage of seeds on germination of non-native invasive plant species, including yellow guava, and concluded that roseringed parakeets were mainly seed predators of these tested species; however, some seeds were passed intact and germinated, and Thabethe et al. (2015) indicated that regurgitation and dropping of uneaten fruits away from the parent plant was a likely means of dispersal. Rose-ringed parakeets had 34-50 min seed retention times when fed yellow guava fruit; these seeds were approximately $0.3-0.5 \mathrm{~cm}$ in diameter and were 100-500 seeds per fruit (Thabethe et al. 2015). During the experimental feeding trials, roseringed parakeets excreted, rather than regurgitated, few yellow guava seeds. It is unknown how many seeds were offered or consumed in these trials, but of the few yellow guava seeds that did pass through the rose-ringed parakeet digestive tract, only about $8 \%$ of these seeds germinated (Thabethe et al. 2015). Thabethe et al. (2015) also reported that seeds contained in whole yellow guava fruit showed significantly lower germination rates than ingested or manually de-pulped seeds. Therefore, it is most probable that the majority of the seeds of yellow guava consumed by rose-ringed parakeets in Kauai or elsewhere are destroyed, but some of these pass intact through their digestive tract and a small percentage of those $(\sim 8 \%$; Thabethe et al. 2015) are expected to survive to germination. Additionally, further spread of yellow guava could arise from dropped and partially eaten fruits, and regurgitation of seeds; these are both likely scenarios on Kauai given how frequently the parakeets feed on yellow guava (Figs. 1,2).

Our study was limited by collections of rose-ringed parakeets from lowland and developed areas of Kauai. From earlier work by Gaudioso et al. (2012), roseringed parakeets on Kauai primarily roost and often forage in the areas where our sampling occurred. However, radio-tagged parakeets habitually left their roost at sunrise, foraged primarily in nearby corn fields, and then traveled north into the higher elevation areas that have a greater proportion of natural areas (Gaudioso et al. 2012). Native plants are common to these natural areas, and given the results of the current study, there could be native seeds that may suffer predation from parakeet feeding. Unfortunately, attempts to harvest parakeets from such natural areas failed, and many of the seeds recovered from crop and gizzards were damaged beyond species identification. Although there are native Acacia koa trees on Kauai in addition to non-native Acacia spp., only the genus Acacia, and not the species of these seeds found in crops and gizzards, was able to be determined via genetic analysis. In addition to seed predation of native species, seed dispersal of both native and nonnative plants by rose-ringed parakeets on Kauai is possible; in addition to yellow guava seeds common in our current study, intact seeds of the invasive Passiflora edulis have been found in crops and gizzards of rose-ringed parakeets on Kauai (Gaudioso et al. 2012). Small seeds, as small as or smaller than yellow guava seeds, would be the most likely to pass intact through parakeet digestive tracts, and many small-seeded species are among the 25 most invasive plants in Hawaii (see Shiels 2011). These plant species are often present in the suburban-natural area habitats that these parakeets frequent (Gaudioso et al. 2012). Additionally, larger seeds (native and non-native) may also be dispersed by rose-ringed parakeets via regurgitation. For example, Thabethe et al. (2015) reported from experimental feeding trials that rose-ringed parakeets regurgitated seeds of camphor (Cinnamomum camphora), which has $0.75 \mathrm{~cm}$ diameter seeds. The body sizes of rose-ringed parakeets also may be important to the likelihood of seed dispersal of larger sized seeds, and our findings that male parakeets have greater masses of food in their crops and gizzards than do females may be one example of how sexual dimorphism may influence the likelihood of seed predation and the relative levels of community- and ecosystem- 
based plant damage. Many native plants in Hawaii have similar sized seeds as camphor, and the relative impacts to native ecosystems from seed predation versus seed dispersal of native and non-native plants by invasive vertebrates may be formidable (see Shiels and Drake 2011 for further discussions).

Stable isotope analyses provide a reasonable complement, and in some cases alternative, to traditional stomach or crop and gizzard content analysis. Unlike stomach or crop and gizzard contents, which do not persist long in the digestive tract, stable isotopes reflect the assimilation of diet contents over time. Based on rose-ringed parakeets on Oahu molting each June (N. Kalodimos, pers. comm.), parakeet feathers that we isotopically analyzed represent approximately $10-12$ months of an individual's average diet prior to capture. Although stable isotope analyses are much less precise than crop and gizzard content analyses at identifying prey items to species (Bearhop et al. 2004), our stable isotope findings from the rose-ringed parakeets collected from southern Kauai appear to match the crop and gizzard content findings that corn is a large component of the parakeet diet and that isotopic signatures of relatively little corn consumption further matched the crop and gizzard contents that were void of corn at the Lihue site. Little $\delta^{15} \mathrm{~N}$ variation among parakeets from different sites reflects parakeets feeding at the same trophic level. Moreover, given our findings and the importance of corn, a $\mathrm{C}_{4}$ plant that carries a distinct $\delta^{13} \mathrm{C}$ signature relative to $\mathrm{C}_{3}$ plants, in the parakeet diet, $\delta^{13} \mathrm{C}$ diet signatures appears to be a viable way to distinguish parakeets feeding behavior and some of their feeding sites.

Findings from our study revealed that rose-ringed parakeets collected from human-altered landscapes on Kauai primarily eat corn and yellow guava, but that a wide range of additional vegetative food items are also consumed, and that there are differences in food consumption among sites (in diet composition) and between sexes (with males generally consuming more than females). When examining the possibilities of invasive parakeet control on Kauai, it is beneficial to know that some of the key food resources are predictable; that is, corn fields and yellow guava trees will likely be damaged by parakeets, and locations with these plants are areas where land managers should expect to find diurnal parakeets and perhaps predictable sites where parakeet control could be implemented. Invasive parakeet impacts to native species and ecosystems on Kauai, if occurring, would result from their gregarious foraging, seed predation habits, and possibly seed dispersal of invasive plants. Several native plant species, including Acacia koa and Pritchardia spp., have seeds consumed, and probably depredated, by rose-ringed parakeets on Kauai (W. Bukoski, pers. obs.). However, yellow guava and additional non-native plant species also may be dispersed by rose-ringed parakeets on Kauai. Our findings that rose-ringed parakeets feed on a more diverse diet than just corn or crop plants, and their potential to disperse at least one invasive species, implies that a range of land managers in agricultural, urban, and natural areas should be concerned with the current expansion of these invasive birds on Kauai and elsewhere.

Acknowledgements We thank Heather Coad, Dean Foster, Israel Leinbach, Rachael Moulton, and Celeste Samra for assisting in diet analysis, and Bert, Cliff, Mel, Michelle, and Robin for harvesting the birds on Kauai. We appreciate Bill Lucy's efforts to help secure funds with the Kauai Invasive Species Council and Garden Isle Resource, Conservation and Development via Pacific Cooperative Studies Unit, University of Hawaii. We thank Jonah Ventures laboratory (Boulder, Colorado) for molecular analysis needed to identify the two unknown seeds.

\section{References}

Ali S, Ripley SD (1969) Handbook of the birds of India and Pakistan, vol 3. Oxford University Press, Oxford

Avery ML, Shiels AB (2017) Monk and rose-ringed parakeets. In: Pitt WC, Beasley JC, Witmer GW (eds) Ecology and management of terrestrial vertebrate invasive species in the United States. CRC Press, Taylor and Francis Group, New York, pp 333-357

Bashir EA (1979) A new "parotrap" adapted from the MAC trap for capturing live parakeets in the field. In: Bird control seminars proceedings, paper 23

Bearhop S, Adams CE, Waldron S, Fuller R, Macleod H (2004) Determining trophic niche width: a novel approach using stable isotope analysis. J Anim Ecol 73:1007-1012

Butler CJ (2003) Population biology of the introduced roseringed parakeet Psittacula krameri in the UK. Dissertation, Department of Zoology, University of Oxford

Clergeau P, Vergnes A (2011) Bird feeders may sustain feral rose-ringed parakeets Psittacula krameri in temperate Europe. Wildl Biol 17:248-252

Craine JM, Angerer JP, Elmore A, Fierer N (2016) Continentalscale patterns reveal potential for warming-induced shifts in cattle diet. PLoS ONE 11:e0161511

Cramp S (1985) Handbook of the birds of Europe, the Middle East and North Africa. The birds of the Western Palearctic, vol IV. Oxford University Press, Oxford 
Dhindsa MS, Saina HK (1994) Agricultural ornithology: an Indian perspective. J Biosci 19:391-402

Fletcher M, Askew N (2007) Review of the status, ecology, and likely future spread of parakeets in England. Central Science Laboratory, York

Gaudioso JM, Shiels AB, Pitt WC, Bukoski WP (2012) Roseringed parakeet impacts on Hawaii's seed crops on the island of Kauai: population estimate and monitoring of movements using radio telemetry. Unpublished Report QA 1874, USDA, National Wildlife Research Center, Hilo, Hawaii

Giambelluca TW, Chen Q, Frazier AG, Price JP, Chen Y-L, Chu P-S, Eischeid JK, Delparte DM (2013) Online rainfall atlas of Hawai'i. Bull Am Meteorol Soc 94:313-316

Jackson AL, Inger R, Parnell AC, Bearhop S (2011) Comparing isotopic niche widths among and within communities: SIBER-Stable Isotope Bayesian Ellipses in R. J Anim Ecol 80:595-602

Koopman ME, Pitt WC (2007) Crop diversification and leads to diverse bird problems in Hawaiian agriculture. Hum Wildl Confl 1:235-243

Lambert MS, Massei G, Bell J, Berry L, Haigh C, Cowan DP (2009) Reproductive success of rose-ringed parakeets Psittacula krameri in a captive UK population. Pest Manag Sci 65:1215-1218

Mukherjee A, Borad CK, Parasharya BM (2000) Damage of roseringed parakeet, Psittacula krameri Bordeat, to safflower, Carthamus tinctorius L. Pavo 38:15-18

Reddy VR (1998) Bird damage to maize crop on student's research farm on Rajendernager, Hyderabad, Andhrapradesh. Pavo 36:77-78

Reddy VR (1999) Intensive damage to maize crop by roseringed parakeet at a student's farm in a maize cultivated crop in Rajendernager, Hyderabad, Andhrapradesh. Indian J For 3:16-18

Renton K (2001) Lilac-crowned parrot diet and food resource availability: resource tracking by a parrot seed predator. Condor 103:62-69
Sani HK, Dhindsa MS, Toor HS (1994) Food of the rose-ringed parakeet, Psittacula krameri, a quantitative study. J Bombay Nat Hist Soc 91:96-103

Sheehey A, Mansfield B. (2015) Wild rose-ringed parakeets Psittacula krameri. Nature Alley. Weldon, California, USA: Nature Alley, unpaginated. http://www.natureali. org/roserings.htm

Shiels AB (2011) Frugivory by introduced black rats (Rattus rattus) promotes dispersal of invasive plant seeds. Biol Invasions 13:781-792

Shiels AB, Drake DR (2011) Are introduced rats (Rattus rattus) both seed predators and dispersers in Hawaii? Biol Invasions 13:883-894

Shiels AB, Flores CA, Khamsing A, Krushelnycky PD, Mosher SM, Drake DR (2013) Dietary niche differentiation among three species of invasive rodents (Rattus rattus, $R$. exulans, Mus musculus). Biol Invasions 15:1037-1048

Shivanarayan N, Babu KS, Ali MH (1981) Breeding biology of the rose-ringed parakeet Psittacula krameri at Maruteru. Pavo 19:92-96

Strubbe D, Matthysen E (2007) Invasive ring-necked parakeets Psittacula krameri in Belgium: habitat selection and impact on native birds. Ecography 30:578-588

Taberlet P, Coissac E, Pompanon F, Gielly L, Miquel C, Valentini A, Vermat T, Corthier G, Brochmann C, Willerslev E (2007) Power and limitations of the chloroplast trn L (UAA) intron for plant DNA barcoding. Nucleic Acids Res 35:e14

Tayleur JR (2010) A comparison of the establishment, expansion and potential impacts of two introduced parakeets in the United Kingdom. In: Proceedings from the BOU conference "The impacts of non-native species". Www. BOUPROC.net

Thabethe V, Wilson A-L, Hart LA, Downs CT (2015) Ingestion by an invasive parakeet reduces germination success of invasive alien plants relative to ingestion by indigenous turaco species in South Africa. Biol Invasions 17:3029-3039 